\title{
Different corporal structures determining the effective production of Red Angus primiparous cows at 24 months of age
}

\section{Diferentes estruturas corporais na produtividade efetiva de vacas primíparas aos 24 meses de idade}

\author{
Eduardo Madeira Castilho ${ }^{1}$; Ricardo Zambarda Vaz ${ }^{2 *}$; Pablo Tavares Costa ${ }^{1}$; Tiago \\ Albandes Fernandes ${ }^{1}$; Gustavo Duarte Farias ${ }^{1}$; Arione Augusti Boligon ${ }^{2}$
}

\begin{abstract}
The objective was to evaluate the production and efficiency of 24-month-old Red Angus primiparous cows of different weights at weaning and repetition of pregnancy. Before calving, the females were managed in natural prairies and fed sweet clover (Lotus corniculatus) and ryegrass (Lolium multiflorum Lam.), with loads of 315 and $501 \mathrm{~kg} \mathrm{ha}^{-1}$, respectively. Females were divided into groups according to the average birth weight into light $346.15 \pm 3.39 \mathrm{~kg}$; moderate $381.95 \pm 2.99 \mathrm{~kg}$; and heavy $412.63 \pm$ $3.33 \mathrm{~kg}$ weights. The indicators evaluated were: primiparous weights and body conditions at calving and weaning, daily average and total gains, fixed-time artificial insemination (FTAI), and accumulation. Calves at birth and weaning had their daily average and total weights evaluated. In terms of production, the daily average and total gains per pair and effective herd production (EHP) of the weight groups were measured. At weaning, morphometric measures, viz. croup height and thoracic perimeter had a linear relationship increasing with the weight at calving. In FTAI and cumulative pregnancy, the groups of light and moderate cows were more efficient than the heavy group cows, with values of $81.25 \%$, $75.00 \%$, and $55.56 \%$, respectively. The EHP differed between the groups with values of $37.07 \pm 1.71$, $28.13 \pm 1.50$, and $19.99 \pm 1.68 \mathrm{~kg}$, for light, moderate, and heavy, respectively. Light cows were $31.8 \%$ and $85.4 \%$ higher in effective production than moderate and heavy cows, respectively. Knowledge of the production system is important for enhancing breeding efficiency. The improvement in productive performance is related to the adequacy of metrices used in the production system.

Key words: Croup height. Body condition. Reproductive performance. Frame. Thoracic perimeter.
\end{abstract}

\section{Resumo}

Objetivou-se avaliar a produção e eficiência de vacas Red Angus primíparas aos 24 meses de diferentes pesos do parto a desmama e a repetição de cria. Antes do parto as fêmeas foram manejadas em pastagens naturais e após em pastagens de cornichão (Lotus corniculatus) e azevém (Lolium multiflorum Lam.) com cargas de 315 e $501 \mathrm{~kg} \mathrm{ha}^{-1}$, respectivamente. As fêmeas foram divididas em grupos de acordo com o peso médio ao parto em leves $346,15 \pm 3,39 \mathrm{~kg}$; moderadas $381,95 \pm 2,99 \mathrm{~kg}$ e pesadas $412,63 \pm 3,33 \mathrm{~kg}$. Os indicadores avaliados foram: nas primíparas pesos e condições corporais ao parto e ao desmame, ganhos médios diários e totais, prenhez da inseminação artificial em tempo fixo (IATF) e acumulada. Nos bezerros foram avaliados pesos ao nascimento e a desmama, ganhos médios diários e totais. Da

1 Mestres, Programa de Pós-Graduação em Zootecnia, Universidade Federal de Pelotas, UFPel, Faculdade de Agronomia Eliseu Maciel, FAEM, Pelotas, RS, Brasil.E-mail: eduardomcastilho@gmail.com; pablocostta@hotmail.com; taf@zootecnista.com.br; gustavo.dfarias@zootecnista.com.br

2 Profs. Drs., Programa de Pós-Graduação em Zootecnia, UFPel, Faculdade de Agronomia Eliseu Maciel, FAEM, Pelotas, RS, Brasil.E-mail: rzvaz@terra.com.br; arioneboligon@yahoo.com.br

* Author for correspondence 
produção mediram-se os ganhos médios diários e totais do par e a produtividade efetiva de rebanho (PER) dos grupos de pesod. Ao desmame as medidas morfométricas de altura de garupa e perímetro torácico tiveram comportamento linear aumentando com os pesos ao parto das vacas. Na prenhez da IATF e acumulada, os grupos das vacas leves e moderadas se mostraram mais eficientes do que as Pesadas com valores de $81,25,75,00$ e 55,56\%, respectivamente. A PER diferiu entre os grupos com valores de $37,07 \pm 1,71,28,13 \pm 1,50$ e 19,99 $\pm 1,68 \mathrm{~kg}$, para leves, moderadas e pesadas, respectivamente. As vacas leves foram 31,8 e 85,4\% superiores na produtividade efetivado que as moderadas e pesadas, respectivamente. O conhecimento do sistema de produção é importante para elevar a eficiência da cria. A melhora no desempenho produtivo está ligada a adequação do tamanho das matrizes para o sistema produtivo.

Palavras-chave: Altura de garupa. Condição corporal. Desempenho reprodutivo. Frame. Perímetro torácico.

\section{Introduction}

In the few last decades, the beef cattle industry in the state of Rio Grande do Sul (RS) has undergone several transformations, which made the adoption of managerial practices focused on the constant search for efficiency and control of the production processes necessary under penalty of unfeasibility or even extinction of the activity. The area occupied by soybean plantations in RS, showed an increase of $31.2 \%$ in the last five years. This expansion occurred largely on areas formerly intended for livestock. Thus, with the greater demand for agricultural areas, less profitable activities started to give way to cultivation of crops with higher production speed and added value (CONAB, 2018). Several factors culminated in the de-structuring of native pastures for the cultivation of annual crops, including those that result in low productive indexes of the herds and low profitability of livestock when used as fodder (BARCELLOS et al., 2008). Baruselli et al. (2002) reported that the productivity of the herd per unit area is low, being less profitable than rearing and fattening activities. This is owing to factors such as long periods for product (calves) and immobilized capital when considering land values and livestock (MARQUES, 2013).

Limited planning in the use of forage resources without taking into account the different seasons of the year and different requirements of the reared animals contributes to low rearing rates (ROCHA et al., 2007), and directly impacts the economic return of livestock breeding (BERETTA et al., 2002).

A younger age at first mating improves the reproductive efficiency of the herd (FONTOURA JÚNIOR et al., 2009). In addition, it allows for greater selection pressure, greater precocity in choosing the best matrices, and a reduction in the interval between generations, with a faster return on investment(VAZ etal., 2012). These females have the potential to produce larger numbers of offspring and wean more kilograms of calves in their productive lives (JAUME et al., 2000). However, investment in mating age reduction should be accompanied by good conception rates in the subsequent reproductive period. As the system intensifies by reducing the age at first mating, obtaining desirable responses in animal performance becomes essential to achieve the objectives proposed by the production system (VAZ et al., 2012).

In addition to these factors, production efficiency in livestock breeding is directly related to the body size of the cows in the herd, which has biological, productive, and economic impacts (SILVA et al., 2015). The objective of the present study, performed in southern Brazil, was to evaluate the production efficiency of 24-month-old Red Angus primiparous cows with different body sizes (weights), in terms of the efficiency of kilogram stock at calving, which is related to production during lactation and repetition of pregnancy in the subsequent mating season. 


\section{Material and Methods}

The present study was carried out based on the technical principles of biosafety and ethics in the use of animals in research, under the approval of the Ethics Committee on Animal Experimentation (ECAE) of the Federal University of Pelotas, for the process $n^{\circ} 23110.008250 / 2015-31$, registered by the Department of Research and Scientific Initiation of the University under the code $n^{\circ}$ ECAE 8250-2015.

The experiment was performed in a private property located in the municipality of Arroio Grande, RS. The region has an average annual precipitation of $1,300 \mathrm{~mm}$, and sandy-loam soil containing $10 \%$ to $15 \%$ clay, with low levels of phosphorus and potassium, and $\mathrm{pH}$ between 5.3 and 5.7 .

The study consisted of analysis and monitoring of performance data of 54 Red Angus primiparous females, at 24 months of age, during their first lactation. At calving, these cows were classified according to their body weight. In relation to the average flock weight $(381.15 \mathrm{~kg})$ and standard deviation $(30.07 \mathrm{~kg})$, the cows were classified into three groups: light cows - weighing less than or equal to half the average standard deviation (average weight of $346.15 \pm 3.39 \mathrm{~kg}$ ); moderate cows weighing more than half the standard deviation below the general average of the flock and less than half the standard deviation above the general average of the flock (average weight of $381.95 \pm$ $2.29 \mathrm{~kg}$ ); and heavy - cows weighing at or above the standard deviation of the total average of the flock (average weight $412.63 \pm 3.33 \mathrm{~kg}$ ).

During the pre-partum period, the females were kept in a natural pasture with stocking rate of $315 \mathrm{~kg} \mathrm{ha}^{-1}$, and in the postpartum period in a cultivated pasture composed of sweet clover (Lotus corniculatus) and ryegrass (Lolium multiflorum Lam.), with animal load of $501 \mathrm{~kg} \mathrm{ha}^{-1}$. The natural pasture predominantly comprised Axonopus affinis (carpetgrass), Paspalum notatum (bahiagrass),
Paspalum dilatatum (dallisgrass), Piptochaetium stipoides (purple speargrass), and Luziola leiocarpa (Peruvian watergrass).

Births occurred between September 05 and November 09 of 2016, with the cows and their calves being identified and weighed within the first $24 \mathrm{~h}$ postpartum and at weaning, with intermediate weighing to monitor and maintain animal loads. The daily average weight variations were determined by the differences between the weighings ( $\mathrm{kg}$ ) divided by the period between them (days).

Weaning was performed when the calves reached an average of 211 days of age (ranging from 184 to 249 days). At this stage, the body measurements of the cows at the croup height (distance from the sacrum to the surface of the ground) and thoracic perimeter were performed, and these measurements were taken with the aid of a square and a measuring tape, respectively. During weighing, the body condition scores of the cows were estimated visually and subjectively, assigning values on a scale of 1-5 (MARQUES, 2013).

The mating method used in the postpartum reproductive season was fixed-time artificial insemination (FTAI), preceded by gynecological evaluation by ultrasonography 30 days before the beginning of the mating season. Subsequently, the cows were mated in a natural mating regime for 60 days, with $4 \%$ of bulls, previously tested for their libido and sperm quality. The gestation diagnosis was performed 30 days after the FTAI and 30 days after the bulls were removed, obtaining pregnancy rates by FTAI and accumulation of FTAI and bulls.

The estimates of productive efficiency were obtained from quantified characteristics. The total weight gains of cows and calves $(\mathrm{kg})$ from calving to weaning were used to estimate production. The production efficiencies at calving and weaning were evaluated, by obtaining the ratio of the weight (in $\mathrm{kg}$ ) of the calves at weaning per $100 \mathrm{~kg}$ of cows at calving and 211 days, respectively (RIBEIRO et al., 2001). 
The rate of calf production was calculated by the association between calf weight at weaning and cow pregnancy rate, with the result in $\mathrm{kg}$ of calves produced by the mated cows (VAZ; LOBATO, 2010).

To calculate the effective herd production (EHP), the total weight $(\mathrm{kg})$ produced by the cowcalf pair were divided by the average weight of the mated cows; then this value was multiplied by the pregnancy rate recorded in the subsequent mating season.

The efficiency of the stock of kilograms of cows (\%) determined the effective production between herds by dividing the percentage of the most efficient herd compared with that in the others, decreasing from 1 and multiplying by 100 .

The experimental design was completely randomized. The data collected were submitted to an analysis of variance, where the size of the cows was a fixed effect and age and sex of the calves were co-variables. The analyses were performed using the GLM procedure. The data were analyzed by the statistical software SAS, version 9.2 (SAS, 2008), adopting $5 \%$ as the level of maximum significance by the $t$-test. The pregnancy rate was analyzed by the chi-square method (GOMEZ; GOMEZ, 1984).

\section{Results}

The body weight of the primiparous cows at birth differed significantly, determining the distribution of cows to the respective groups. The "heavy" group continued to weigh more heavily than the other groups at weaning; however, the difference between "light" and "moderate" was no longer present (Table 1). At weaning the cows weighed $373.03 \pm 8.23,391.81 \pm 7.24$, and $422.29 \pm 8.08 \mathrm{~kg}$ for light, moderate, and heavy, respectively.
The evaluation of the body condition score at birth showed a similarity between the groups, where the light, moderate, and heavy groups obtained $3.15 \pm 0.07,3.16 \pm 0.06$ and $3.18 \pm 0.06$ points, respectively. This is important because it shows that the groups are different according to the size of the cows, with no effect from muscular deposition and body fat.

During lactation a reduction in body score occurred in the three groups with values of -0.055 $\pm 0.067,-0.043 \pm 0.059$, and $-0.023 \pm 0.023 \mathrm{~kg}$, for mild, moderate and heavy, respectively.

Daily average variation in cow weight during lactation did not differ between groups, with values of $0.134 \pm 0.038,0.047 \pm 0.033$, and $0.043 \pm 0.037$ $\mathrm{kg}$, for light, moderate and heavy cows, respectively. The accumulated cow weight gains during the lactation period were $26.8 \pm 7.6,9.8 \pm 6.7$, and $9.6 \pm$ $7.5 \mathrm{~kg}$, for light, moderate, and heavy, respectively.

Weaning measures revealed the superiority of the heavy primers over the lightweight groups in terms of both thoracic perimeter and croup height, showing differences in body structure between the groups under study.

The performance of the calves was not influenced by the size of the mother, presenting similar values for weights at birth and weaning, as well as for daily average variations and total weight gain during the lactation period. The body weight gains of the cow-calf pair were similar between the groups with values of $156.73 \pm 8.63,142.96 \pm 7.60$, and 149.92 $\pm 8.48 \mathrm{~kg}$, for light, moderate cows and heavy, respectively.

The rate of repetition of pregnancy of primiparous cows was influenced by cow size, with cows in the light $(81.25 \%)$ and moderate $(75.00 \%)$ groups being more superior than those in the heavy group $(55.56 \%)$. 
Table 1. Averages and standard errors for development, reproduction, and efficiency characteristics of Red Angus primiparous cow herds of different body sizes.

\begin{tabular}{|c|c|c|c|}
\hline Characteristics & Light & Moderate & Heavy \\
\hline & \multicolumn{3}{|c|}{ Cows } \\
\hline Number of animals per group & 16 & 20 & 18 \\
\hline Average birth weight, $\mathrm{kg}$ & $346.2 \pm 3.39^{c}$ & $381.9 \pm 2.99^{b}$ & $412.6 \pm 3.33^{\mathrm{a}}$ \\
\hline Average weight at weaning (211 days), $\mathrm{kg}$ & $373.0 \pm 8.23^{\mathrm{bc}}$ & $391.8 \pm 7.24^{\mathrm{b}}$ & $422.3 \pm 8.08^{\mathrm{a}}$ \\
\hline Body condition at birth, points & $3.15 \pm 0.07$ & $3.16 \pm 0.06$ & $3.18 \pm 0.06$ \\
\hline Body condition at weaning, points & $3.10 \pm 0.06$ & $3.12 \pm 0.05$ & $3.15 \pm 0.04$ \\
\hline Daily average weight gain in lactation, $\mathrm{kg}$ & $0.134 \pm 0.04$ & $0.047 \pm 0.03$ & $0.043 \pm 0.04$ \\
\hline Total weight gain in lactation, $\mathrm{kg}$ & $26.88 \pm 7.68$ & $9.86 \pm 6.76$ & $9.65 \pm 7.55$ \\
\hline Thoracic circumference at weaning, meters & $1.73 \pm 0.01^{\mathrm{b}}$ & $1.75 \pm 0.01^{\mathrm{ab}}$ & $1.78 \pm 0.01^{\mathrm{a}}$ \\
\hline \multirow[t]{2}{*}{ Height of croup at weaning, meters } & $1.30 \pm 0.01^{\mathrm{c}}$ & $1.33 \pm 0.01^{\mathrm{b}}$ & $1.36 \pm 0.01^{\mathrm{a}}$ \\
\hline & \multicolumn{3}{|c|}{ Calves } \\
\hline Weight at birth, kg & $46.65 \pm 1.92$ & $48.30 \pm 1.69$ & $50.06 \pm 1.88$ \\
\hline Weaning weight (211 days), kg & $176.49 \pm 5.85$ & $181.40 \pm 5.15$ & $189.33 \pm 5.75$ \\
\hline Daily average weight gain in lactation, $\mathrm{kg}$ & $0.63 \pm 0.03$ & $0.64 \pm 0.02$ & $0.65 \pm 0.03$ \\
\hline \multirow[t]{2}{*}{ Total weight gain in lactation, $\mathrm{kg}$} & $129.84 \pm 5.90$ & $133.10 \pm 5.19$ & $139.26 \pm 5.79$ \\
\hline & \multicolumn{3}{|c|}{ Production Efficiency } \\
\hline FTAI pregnancy, $\%$ & $43.75^{\mathrm{B}}$ & $65.0^{\mathrm{A}}$ & $30.00^{\mathrm{B}}$ \\
\hline Cumulated pregnancy (FTAI + Bulls), $\%$ & $81.25^{\mathrm{A}}$ & $75.00^{\mathrm{A}}$ & $55.56^{\mathrm{B}}$ \\
\hline Total cow/calf weight gain, $\mathrm{kg}$ & $156.73 \pm 8.6$ & $142.96 \pm 7.6$ & $149.92 \pm 8.5$ \\
\hline Average daily gain of cow/calf pair, $\mathrm{kg}$ & $0.76 \pm 0.04$ & $0.69 \pm 0.04$ & $0.69 \pm 0.04$ \\
\hline Productive efficiency at calving, $\mathrm{kg}^{1}$ & $12.6 \pm 0.6$ & $12.4 \pm 0.5$ & $12.0 \pm 0.6$ \\
\hline Productive efficiency at weaning, $\mathrm{kg}^{2}$ & $47.6 \pm 1.8$ & $46.7 \pm 1.6$ & $45.1 \pm 1.8$ \\
\hline Index of production of calves, $\mathrm{kg}^{3}$ & $144.0 \pm 4.1^{\mathrm{a}}$ & $136.2 \pm 3.6^{\mathrm{a}}$ & $104.9 \pm 4.0^{\mathrm{b}}$ \\
\hline Effective herd productivity,\% & $37.07 \pm 1.71^{\mathrm{a}}$ & $28.13 \pm 1.50^{\mathrm{b}}$ & $19.99 \pm 1.68^{\mathrm{c}}$ \\
\hline Relation between effective yields of herds (Light as reference), $\%$ & & 31.80 & 85.40 \\
\hline
\end{tabular}

a, b, c Averages followed by different lowercase letters in rows differ $(\mathrm{P}<0.05)$ for the t-test. ${ }^{\mathrm{A}, \mathrm{B}}$ Averages followed by different capital letters in rows differ $(\mathrm{P}<0.05)$ by the chi-square test. ${ }^{1}$ Calf weight at 210 days $\times$ pregnancy rate $/ 100=\mathrm{kg}$ of calf per cow kept in the herd; ${ }^{2}$ Weight of calves at 210 days / Weight of cow at calving $\times 100=$ calf $\mathrm{kg} / 100 \mathrm{~kg}$ cow; ${ }^{3}$ Weight of calves at 210 days / Weight of cow at 210 days $\times 100=\mathrm{kg}$ of calf $/ 100 \mathrm{~kg}$ of cow.

The productive efficiencies at calving and weaning did not differ among cow body size groups. When analyzing the calf production index (VAZ; LOBATO, 2010) that associates calf weaning weight with the cow's pregnancy rate, the light and moderate cows had a better index than the heavy cows, with values of $144.0 \pm 4.1,136.2 \pm 3.6$, and $104.9 \pm 4.0 \mathrm{~kg}$, in the three groups, respectively. The effective production of the herds was $37.07 \pm$
$1.71 \%, 28.13 \pm 1.50 \%$, and $19.99 \pm 1.68 \%$, for light, moderate, and heavy cows, respectively.

Regarding production, light cows were more efficient $(37.07 \%)$, followed by moderate cows $(28.13 \%)$, and heavy cows were the least efficient (19.99\%). Relatively, the efficiency values demonstrated a superiority of the light cows by $31.8 \%$ and $85.4 \%$ over that of the moderate and heavy cows, respectively. 


\section{Discussion}

Cow weight at calving and weaning is an important factor in the productive and reproductive performance of the herds. Higher cow weights at calving and weaning, within the same frame, are correlated with higher calf weights at weaning (VAZ et al., 2014) and better reproductive performance of beef cows (SANTOS et al., 2009). However, in the present study, the largest body size of the cows was related to the weight of the herd. This could be detrimental, especially when environmental conditions are not ideal, and may influence the reproductive performance of cows (SILVA et al., 2015). This could be aggravated when the cows are primiparous, and may result in impaired reproductive performance or future development (CERDÓTES et al., 2004). However, the effects under favorable environmental and nutritional conditions have not been verified (PILAU; LOBATO, 2009).

Studying the nutritional requirements of the different categories is fundamental for the appropriate animal response. Primiparous cows have a higher postpartum metabolic demand than multiparous cows owing to lactation and calving stress, which is also potentiated since the cow is still in the growth phase (WILTBANK et al., 1985). Therefore, these can have greater effects, owing to the animal size, and increase of nutritional requirements of the different animal types. The nutritional requirements of the groups of weights under study are variable, where light-weight cows require $639.73 \mathrm{~g}$ day $^{-1}$ of raw protein and $11.17 \mathrm{Mcal}$ day $^{-1}$ of raw energy for their maintenance, growth and lactation, whereas moderate-weight cows need $671.45 \mathrm{~g} \mathrm{day}^{-1}$ and $11.81 \mathrm{Mcal}^{\mathrm{day}}{ }^{-1}$ gross energy, and heavy-weight cows require $707.39 \mathrm{~g} \mathrm{day}^{-1}$ and 12.46 Mcal day-1 gross energy (NRC, 2000). These values demonstrate that light-weight cows need approximately $4.72 \%$ and $9.56 \%$ raw less protein than, moderate- and heavy-weight cows, as well as about $5.42 \%$ and $10.35 \%$ less gross energy, respectively.
During lactation, the primiparous cows experienced a loss of condition and small gains in body weight. Subsequent reproduction of primiparous cows is positively correlated with positive body weight variations, that is, the higher the daily weight gain, the greater the subsequent reproductive success (PILAU; LOBATO, 2009). The chances of conception in beef cows increased from the time when the cows did not lose weight. For each $0.1 \mathrm{~kg} \mathrm{day}^{-1}$ of positive body variation during the mating period, the rate of conception increased by $17.9 \%$, in Nelore $\times$ Hereford cows in subtropical environments (GRECELLÉ et al., 2006), and $7.47 \%$ in Nelore cows in the Pantanal, Mato Grosso do Sul State (BATISTA et al., 2012).

In addition, first-calf cows with good body condition postpartum have reduced postpartum anestrus, thus raising conception rates (WILTBANK et al., 1985). The average pregnancy rate of the primiparous cows in the present study $(70.0 \%)$ may be considered high for the Rio Grande do Sul levels, which presents a pregnancy repetition rate of $56 \%$ (SILVA et al., 2015). Vaz and Lobato (2010) verified repetition of pregnancy rates similar to those of the present study, but in primiparous cows at 36 months of age; when calves were weaned early at 67 days of age, the percentage of rearing increased from $40.0 \%$ to $91.4 \%$.

In the present study, postpartum cows were maintained on sweet clover and ryegrass pastures, which, if well managed, provide a nutritional level close to the ideal, for the category under study. This fact is strengthened by the fact that the animals are smaller and, consequently, less demanding, resulting in greater weight gains and better body conditions (NRC, 2000). No differences in weight gain during lactation and calf weight at weaning demonstrated that there were three potential body sizes for calf growth in this productive system. However, the equal performance of the calves may be owing to greater stress of the cow, which tries to produce more milk for the calf based on its 
requirements (VIEIRA et al., 2005), and undergoing greater stress in adverse environmental conditions (PILAU; LOBATO, 2009). The performance of the calf from birth to weaning is directly related to a combination of factors, such as calf genotype, breeding environment, and maternal ability (VIU et al., 2006).

The height of heifers is an important source of variation of the animals, and is less susceptible to environmental factors than body weight (VARGAS et al., 1999). Higher croup height, in addition to genetics, may be positively correlated with the energy intake of the animals' diet (REZENDE et al., 2011), in addition to increased stature correlated with increased body size of cattle (VAZ et al., 2016a). Metabolic body size is associated with nutritional requirements (BIF, 2014). For Pereira et al. (2000), when animal selection is based on body weight, larger animals are produced, which may be later and/or less efficient.

The thoracic perimeter is the body measurement with the lowest variation and most accurate for determining muscle growth (PACHECO et al., 2008). Body size may be related to the weight of the animals, where taller animals are the later ones, considering the morphometric characteristics, avoiding the use of extreme types, which would have negative correlations with the animal production (SOUZA et al., 2002). Larger developments in thoracic perimeter measurements are usually expressed, owing to greater depositions of muscle and adipose tissue, which have growth curves different from those of the skeleton, which ceases to grow when maturity is reached (ROCHA et al., 2003).

Although without significant differences, the lower values of daily weight variations, loss of body condition during lactation, and maintenance of calf growth, subsequent reproductive outcomes are potentiated. Increases in body size decreased the repetition of pregnancy rates in primiparous cows, with values of $81.00 \%, 75.00 \%$ and $55.56 \%$ for light, moderate, and heavy cows, respectively. The nutritional requirements of cows primarily affect their maintenance, growth, gestation, and lactation, and not reproduction (DUARTE JÚNIOR et al., 2013).

The pregnancy rates of the groups reflect the productive system with cows, where lower demand results in greater reproductive successes. The selection of animals should seek a genotype adapted to the environment, such as the production capacity in short cycle systems, maintaining or reducing adult size, maintenance needs, and age at puberty and slaughter without increasing nutritional requirements (McMANUS et al., 2002). According to Magnabosco et al. (2009), higher weight at cow maturity, in extensive breeding systems, is associated with performance losses. Higher weight in nonideal conditions increased the calving interval, reducing reproductive efficiency, leading to higher maintenance costs, and reducing the production of kilograms of calves per cow during its lifetime. The same author concluded that the productive and economic efficiency of a herd depends on the size of its matrices, since extensive systems usually pass through supply seasonality and quality of food during the year.

Evaluating only the conception of the cows by FTAI, it is verified that cows of moderate size were more efficient when than light and heavy cows. Although not significantly different $(\mathrm{P}>0.05)$, body condition in primiparous cows was fundamental to the success of FTAI. Primiparous cows with higher body condition scores at the beginning of the synchronization protocol obtained a higher conception rate with FTAI (MENEGHETTI; VASCONCELOS, 2008). In addition, uterine involution and return of ovarian activity in females are also related to good body condition at birth.

The productive efficiency at weaning is an indicator measuring the ratio of kilograms of calves weaned for each $100 \mathrm{~kg}$ of cow kept in the herd. Although not significantly different, light, 
moderate, and heavy cows show similar abilities as progenitors, and could be considered good since they wean calves weighing around $50 \%$ of their weight (MAGNABOSCO et al., 2009). Vaz et al. (2016b), when working with only two animal sizes in an Abeerden Angus herd, verified greater efficiencies at weaning from light cows than those from heavy cows, with values higher than $50 \%$ for the former. In addition to the size of the cow, the productive efficiency at weaning could be influenced by the age of weaning (VAZ; LOBATO, 2010), breed (RIBEIRO et al., 2001), mating system, level of food avaiable to the herd (VAZ et al., 2014), and cow milk production (VAZ et al., 2016a).

The rate of calf production is an important indicator of the association of calf production and subsequent rate of reproduction. There is no point in producing a heavy calf if the cow is not pregnant again and is therefore not considered productive. The probable kilograms of calves produced in the herds for the subsequent mating season could be increased through the age of weaning (VAZ; LOBATO, 2010), use of cultivated pastures and mating systems (VAZ et al., 2014), and size of cows (VAZ et al., 2016a).

Effective herd production is an indicator developed to assess whether the one-year production of a herd interferes with subsequent crop production, as it correlates the productivity of kilograms of the pair (cow-calf) with the repetition rate of pregnancy the following year. Therefore, it can evaluate the production efficiency of kilogram stock at birth for the next calving season.

When comparing the effective productivity between the groups alone, based on the light-weight cows, it was verified that this group has a higher efficiency of $31.8 \%$ than moderate-weight cows, and $85.4 \%$ than heavy-weight cows. Considering the effective productivity values of the respective groups, as well as their energy and protein demand, according to the NRC (2000), the light-weight group was $25 \%$ more efficient than the moderate- weight group, and $67 \%$ more efficient than the heavy-weight cows.

\section{Conclusions}

Red Angus primiparous cows of different sizes had the same production efficiency at calving and weaning.

Light- and moderate-weight cows had better reproductive performance and, when associated with calf development, were more productive than heavy-weight cows.

\section{References}

BARCELLOS, A. O.; RAMOS, A. K. B.; VILELA, L.; MARTHA JUNIOR, G. B. Sustentabilidade da produção animal baseada em pastagens consorciadas e no emprego de leguminosas exclusivas, na forma de banco de proteína, nos trópicos brasileiros. Revista Brasileira de Zootecnia, Viçosa, MG, v. 37, n. 1, p. 51-67, 2008, Suplemento Especial.

BARUSELLI, P. S.; MARQUES, M. O.; CARVALHO, N. A. T.; MADUREIRA, E. H.; CAMPOS FILHO, E. P. Efeito de diferentes protocolos de inseminação artificial em tempo fixo na eficiência reprodutiva de vacas de corte lactantes. Revista Brasileira de Reprodução Animal, Belo Horizonte, v. 26, n. 3, p. 218-221, 2002.

BATISTA, D. S. N.; ABREU, U. G. P.; FERRAZ FILHO, P. B.; ROSA, A. N. Índices reprodutivos do rebanho Nelore da fazenda Nhumirim Pantanal da Nhecolândia. Acta Scientiarum. Animal Sciences, Maringá, v. 34, n. 1, p. 71-76, 2012.

BEEF IMPROVEMENT FEDERATION - BIF. Guidelines for uniform beef improvement programs. $7^{\text {th }}$ ed. Athens: Beef Improvement Federation and North Carolina State University, 2014. 182 p.

BERETTA, V.; LOBATO, J. F. P.; MIELITZ NETTO, C. G. Produtividade e eficiência biológica de sistemas de produção de gado de corte de ciclo completo no Rio Grande de Sul. Revista Brasileira de Zootecnia, Viçosa, MG, v. 31, n. 2, p. 991-1001, 2002.

CERDÓTES, L.; RESTLE, J.; ALVES FILHO, D. C.; PACHECO, P. S.; MISSIO, R. L.; GARAGORRY, F. C. Desempenho de bezerros de corte filhos de vacas submetidas a diferentes manejos alimentares, desmamados aos 42 ou 63 dias de idade. Revista Brasileira de Zootecnia, Viçosa, MG, v. 33, n. 3, p. 597- 
609, 2004.

COMPANHIA NACIONAL DE ABASTECIMENTO - CONAB. Indicadores da Agropecuária / Companhia Nacional de Abastecimento. Cidade: Brasília, Editora: Conab, 2018. Disponível em: <https://www.conab. gov.br/info-agro/precos/revista-indicadores-daagropecuaria $>$. Acesso em: 02 ago. 2018.

DUARTE JÚNIOR, M. F.; HATAMOTOZERVOUDAKIS, L. K.; ZERVOUDAKIS, J. T. Aspectos relacionados à fisiologia do anestro pós-parto em bovinos. Colloquium Agrariae, São Paulo, v. 9, n. 2, p. 43-71, 2013.

FONTOURA JÚNIOR, J. A. S.; SIEWERDT, F.; DIONELLO, N. J. L.; CORRÊA, M. N. Modelo de simulação do desempenho reprodutivo de fêmeas bovinas de corte com base no escore de condição corporal. Revista Brasileira de Zootecnia, Viçosa, MG, v. 38, n. 8, p. 1627-1635, 2009.

GOMEZ, K. A.; GOMEZ, A. A. Statistical procedures for agricultural research. $2^{\text {th }}$ ed. New York: John Wiley and Sons, 1984. $680 \mathrm{p}$.

GRECELLÉ, R. A.; BARCELLOS, J. O. J.; BRACCINI NETO, J.; COSTA, E. D.; PRATES, E. R. Taxa de prenhez de vacas Nelore x Hereford em ambiente subtropical sob restrição alimentar. Revista Brasileira de Zootecnia, Viçosa, MG, v. 35, n. 4, p. 1423-1430, 2006.

JAUME, C. M.; SOUZA, C. J. H.; MORAES, J. C. F. Aspectos da reprodução em gado de cria. Bagé: EMBRAPA Pecuária Sul, 2000. 48 p. (EMBRAPA Pecuária Sul. Documentos, 20).

MAGNABOSCO, C. U.; PAULA, E. J. H.; VIU, M. A. O.; LOPES, D. T.; PASCOA, L.; BARIONI, L. G. Simulação da evolução do rebanho considerando o potencial de crescimento e habilidade materna como critérios de seleção em bovinos de corte. Planaltinas: EMBRAPA Cerrados, 2009. 26 p. (EMBRAPA Cerrados. Boletim de Pesquisa e Desenvolvimento, 259).

MARQUES, P. R. Planejamento e gestão do sistema de cria. In: MENEGASSI, S. R. O.; CANELLAS, L. C.; MARQUES, P. R.; MOOJEN, F. G.; AZEVEDO, E. V. T.; EVANGELISTA, G. T.; MERCIO, T. Z.; COSTA JÚNIOR, J. B. G.; BARCELLOS, J. O. J. (Ed.). Manejo de sistemas de cria na pecuária de corte. Guaíba: Agrolivros, 2013. p. 141-155.

McMANUS, C.; SAUERESSIG, M. G.; FALCÃO, R. A.; SERRANO, G.; MARCELINHO, K. R. A.; PALUDO, G. R. Componentes reprodutivos e produtivos no rebanho de corte da EMBRAPA Cerrados. Revista Brasileira de Zootecnia, Viçosa, MG, v. 31, n. 2, p. 648-657, 2002.

MENEGHETTI, M.; VASCONCELOS, J. L. M. Mês de parição, condição corporal e resposta ao protocolo de inseminação artificial em tempo fixo em vacas de corte primíparas. Arquivo Brasileiro de Medicina Veterinária e Zootecnia, Belo Horizonte, v. 60, n. 4, p. 786-793, 2008.

NATIONAL RESEARCH COUNCIL - NRC. Nutrients requirements of beef cattle. $7^{\text {th }}$ ed. Washington: The National Academy Press, 2000. 248 p.

PACHECO, A.; QUIRINO, C. R.; PINHEIRO, O. L. V. M.; ALMEIDA, J. V. C. Medidas morfométricas de touros jovens e adultos da raça Guzerá. Revista Brasileira de Saúde e Produção Animal, Salvador, v. 9, n. 3, p. 426435, 2008.

PEREIRA, L. P.; RESTLE, J.; BRONDANI, I. L.; ALVES FILHO, D. C.; SILVA, J. H. S.; MUEHLMANN, L. D. Desenvolvimento ponderal de bovinos de corte de diferentes grupos genéticos de charolês x nelore inteiros ou castrados aos oito meses. Ciência Rural, Santa Maria, v. 30 , n. 6 , p. 1033-1039, 2000 .

PILAU, A.; LOBATO, J. F. P. Desenvolvimento e desempenho reprodutivo de vacas primíparas aos 22/24 meses de idade. Revista Brasileira de Zootecnia, Viçosa, MG, v. 38, n. 4, p. 728-736, 2009.

REZENDE, P. L. P.; RESTLE, J.; FERNANDES, J. J. L.; PÁDUA, J. T.; FREITAS NETO, M. D.; ROCHA, F. M. Desempenho e desenvolvimento corporal de bovinos mestiços submetidos a níveis de suplementação em pastagem de Brachiaria brizantha. Ciência Rural, Santa Maria, v. 41, n. 8, p. 1453-1458, 2011.

RIBEIRO, E. L. A.; RESTLE, J.; ROCHA, M. A. da; MIZUBUTI, I. Y.; SILVA, L. D. F. Eficiência produtiva em vacas primíparas das raças Aberdeen Angus e Charolês. Revista Brasileira de Zootecnia, Viçosa, MG, v. 30, n. 1, p. 125-132, 2001.

ROCHA, E. D.; ANDRADE, V. J.; EUCLIDES FILHO, K.; NOGUEIRA, E.; FIGUEIREDO, G. R. Tamanho de vacas Nelore adultas e seus efeitos no sistema de produção de gado de corte. Arquivo Brasileiro de Medicina Veterinária e Zootecnia, Belo Horizonte, v. 55, n. 4, p. 474-479, 2003.

ROCHA, M. G.; POTTER, L.; ROSO, D.; GOTTSCHALL, C. Sistemas intensivos de produção de bovinos de corte - ênfase na recria de fêmeas. In: CICLO DE PALESTRAS EM PRODUÇÃO E MANEJO DE BOVINOS, 12., 2007, Canoas. Anais... Canoas: Editora ULBRA, 2007. p. 53-84.

SANTOS, S. A.; ABREU, U. G. P.; SOUZA, G. S.; CATTO, J. B. Condição corporal, variação de peso e desempenho reprodutivo de vacas de cria em pastagem nativa no pantanal. Revista Brasileira de Zootecnia, Viçosa, MG, v. 38, n. 2, p. 354-360, 2009. 
SILVA, R. M.; SOUZA, J. C.; FERNANDES, H. J.; ABREU, U. G. P.; FERRAZ FILHO, P. B.; ROSA, A. N. Eficiência produtiva ao desmame de vacas Nelore criadas no Pantanal. Arquivo Brasileiro de Medicina Veterinária e Zootecnia, Belo Horizonte, v. 67, n. 4, p. 1105-1110, 2015.

SOUZA, J. C.; MALHADO, C. H. M.; SILVA, L. O. C.; FERRAZ FILHO, P. B. Efeito do ambiente sobre o peso de bovinos da raça Guzerá no estado de São Paulo. Archives of Veterinary Science, Curitiba, v. 7, n. 1, p. 57 63, 2002.

SAS Institute Inc. 2008. SAS/STAT® 9.2 User's Guide. Cary, NC: SAS Institute Inc.

VARGAS, C. A.; OLSON, T. A.; CHASE JÚNIOR, C. C.; HAMMOND, A. C.; ELZO, M. A. Influence of frame size and body condition score on performance of Brahman cattle. Journal of Animal Science, Champaign, v. 77, n. 12, p. 3140-3149, 1999.

VAZ, R. Z.; LOBATO, J. F. P. Effects of the weaning age of calves on somatic development and on reproductive performance of beef cows. Revista Brasileira de Zootecnia, Viçosa, MG, v. 39, n. 5, p. 1058-1067, 2010.

VAZ, R. Z.; LOBATO, J. F.; RESTLE, J. Análise de eficiência econômica de sistemas de cria com diferentes idades de desmame dos bezerros. Bioscience Journal, Uberlandia, v. 30, n. 6, p. 1837-1845, 2014.

VAZ, R. Z.; RESTLE, J.; PACHECO, P. S.; VAZ, F. N.; MUEHLMANN, L. D.; ALVES FILHO, D. C.; MISSIO, R. L.; VAZ, M. B. Genetic group and heterosis on morphometric measurements during the growth of male beef Cattle. Semina: Ciências Agrárias, Londrina, v. 37, n. 4, p. 2759-2772, 2016b. Suplemento 1.

VAZ, R. Z.; RESTLE, J.; PACHECO, P. S.; VAZ, F. N.; PASCOAL, L. L.; NEIVA, J. N. M.; DONICHT, P. A. M. M. Performance of beef cows of different genetic groups in natural and cultivated pastures. Bioscience Journal, Uberlandia, v. 32, n. 1, p. 191-201, 2016 a.

VAZ, R. Z.; RESTLE, J.; PACHECO, P. S.; VAZ, F. N.; PASCOAL, L. L.; VAZ, M. B. Ganho de peso pré e pós-desmame no desempenho reprodutivo de novilhas de corte aos quatorze meses de idade. Ciência Animal Brasileira, Goiás, v. 13, n. 3, p. 272-281, 2012.

VIEIRA, A.; LOBATO, J. F. P.; TORRES JUNIOR, R. A. A.; CEZAR, I. M.; CORREA, E. S. Fatores determinantes do desempenho reprodutivo de vacas Nelore na região dos cerrados do Brasil Central. Revista Brasileira de Zootecnia, Viçosa, MG, v. 34, n. 6, p. 2408-2416, 2005.

VIU, M. A. O.; LOPES, D. T.; GAMBARINI, M. L.; OLIVEIRA FILHO, B. D.; FERRAZ, H. T.; MAGNABOSCO, C. U.; VIU, A. F. M. Efeito da época do parto, idade materna e sexo sobre o desempenho prédesmama de bezerros Nelore (Bos taurus indicus), criados extensivamente no centro-oeste do Brasil. Archives of Veterinary Science, Curitiba, v. 11, n. 3, p. 75-79, 2006.

WILTBANK, J. N.; ROBERTS, S.; NIX, J.; ROWDEP, L. Reproductive performance and profitability of heifers fed to weigh 272 or $318 \mathrm{~kg}$ at the start of the first breeding season. Journal of Animal Science, Champaign, v. 60, n. 1, p. 25-34, 1985. 